Jurnal Akuntansi \& Perpajakan, Volume 2, No. 1, Juli 2020

\title{
Pengaruh Literasi Keuangan, Tingkat Suku Bunga, Kualitas Pelayanan dan Jaminan terhadap Pengambilan Kredit Perbankan oleh UKM
}

\author{
Hary Prabowo*, Eliada Herwiyanti, Umi Pratiwi \\ Fakultas Ekonomi dan Bisnis \\ Universitas Jenderal Soedirman, Indonesia \\ Email Corresponding author: eliada.herwiyanti@unsoed.ac.id
}

\begin{abstract}
This study aims to determine the effect of financial literacy, interest rates, service quality, and collateral for the taking of bank loans by SMEs. This study uses primary data, with the SME population registered with the Department of Trade, Cooperatives and SMEs. The sampling technique used purposive sampling with clusters to the sampling center and divided based on the proportion of business units, so that 100 samples were obtained. The data analysis technique used in the study is multiple linear regression analysis.

The results of this study indicate that: (1) financial literacy has a positive and significant effect on the taking of bank loans by SMEs; (2) interest rates do not affect the taking of bank loans by SMEs; (3) service quality has a positive and significant effect on the taking of bank loans by SMEs; (4) collateral have a positive and significant effect on the taking of bank loans by SMEs.

The implication of this research is to improve the financial literacy of SMEs, then improve the quality of services and simplify the collateral requirements for the banking sector in order to further increase credit taking. For the government, this research is expected to be taken into consideration in determining policies relating to the SME and banking sectors.
\end{abstract}

Keywords: Financial Literacy, Interest Rate, Service Quality, Collateral, Taking Credit Banking by SMEs.

\begin{abstract}
ABSTRAK
Penelitian ini bertujuan untuk mengetahui pengaruh literasi keuangan, tingkat suku bunga, kualitas pelayanan, dan jaminan terhadap pengambilan kredit perbankan oleh UKM. Penelitian ini menggunakan data primer, dengan populasi UKM yang terdaftar pada Dinas Perdagangan, Koperasi dan UKM. Teknik pengambilan sampel menggunakan purposive sampling dengan cluster terhadap pusat pengambilan sampel dan dibagi berdasarkan proporsi unit usaha, sehingga didapatkan 100 sampel. Teknik analisis data yang digunakan dalam penelitian adalah analisis regresi linear berganda. Hasil penelitian ini menunjukkan bahwa: (1) literasi keuangan berpengaruh positif dan signifikan terhadap pengambilan kredit perbankan oleh UKM; (2) tingkat suku bunga tidak berpengaruh terhadap pengambilan kredit perbankan oleh UKM ; (3) kualitas pelayanan berpengaruh positif dan signifikan terhadap pengambilan kredit perbankan oleh UKM; (4) jaminan berpengaruh positif dan signifikan terhadap pengambilan kredit perbankan oleh UKM. Implikasi dari penelelitian ini yaitu untuk meningkatkan literasi keuangan para pelaku UKM, selanjutnya peningkatan kualitas pelayanan dan mempermudah syarat jaminan bagi pihak perbankan agar semakin meningkatkan pengambilan kredit. Bagi pemerintah, penelitian ini diharapkan dapat dijadikan bahan pertimbangan dalam menentukan kebijakan yang berkaitan dengan sektor UKM dan perbankan.
\end{abstract}

Kata Kunci : Literasi Keuangan, Tingkat Suku Bunga, Kualitas Pelayanan, Jaminan, Pengambilan Kredit Perbankan Oleh UKM.

Korespondensi : Eliada Herwiyanti. Universitas Jenderal Soedirman. email : $\underline{\text { eliada.herwiyanti@ unsoed.ac.id }}$ 
Jurnal Akuntansi \& Perpajakan, Volume 2, No. 1, Juli 2020

\section{PENDAHULUAN}

Usaha Kecil Menengah (UKM) dewasa ini terus berkembang dan berperan dalam penyerapan tenaga kerja. Perkembangan UKM selama 5 tahun dari tahun 2009 sampai 2013 mengalami peningkatan rata-rata sebesar 1 juta unit usaha. Hingga saat ini jumlah UKM termasuk Usaha Mikro mencapai 57,89 juta unit atau 99,99\% terhadap total usaha di Indonesia. Kabupaten Cilacap merupakan kabupaten di Provinsi Jawa Tengah yang perkembangan UKM-nya terus berkembang. Berdasarkan data dari Dinas Perdagangan, Koperasi dan UKM Kabupaten Cilacap per 2017, jumlah UKM saat ini sebanyak 1.870 unit.

Perkembangan UKM saat ini tidak terlepas dari berbagai masalah, salah satunya adalah masih banyak UKM yang sulit mendapatkan modal. Hal ini disebabkan oleh beberapa faktor, salah satunya adalah sulitnya mengambil pinjaman di bank atau lembaga penyedia pinjaman lainnya. Pengambilan kredit oleh UKM di perbankan atau lembaga keuangan lainnya masih terkendala dengan kurangnya pengetahuan pelaku UKM mengenai tata cara pengajuan pinjaman (Bramantyo dan Sagoro, 2017).

Survei yang dilakukan OJK pada tahun 2013 menunjukkan tingkat literasi keuangan masyarakat Indonesia khususnya daerah pedesaan dan daerah terpencil masih sangat rendah. Baru sebesar 21,84\% dari masyarakat Indonesia yang telah melek keuangan (well literate) dengan tingkat penggunaan layanan keuangan formal hanya sebesar 59,74\% (Zuraya, 2016). Literasi keuangan sendiri merupakan kesadaran dan pengetahuan tentang produkproduk keuangan, lembaga keuangan, dan konsep mengenai keterampilan dalam mengelola keuangan (Xu dan Zia, 2012).

Rendahnya akses jasa keuangan formal yang disebabkan rendahnya literasi keuangan di Indonesia membuat penyaluran kredit UKM yang dilakukan oleh perbankan di Indonesia juga tergolong rendah.. Rata-rata pembiayaan UKM oleh bank di Asia memiliki rasio 11,6\% terhadap Gross Domestic Product (GDP), sedangkan untuk Indonesia penyaluran kredit UKM baru sebesar 7,1\% terhadap GDP, sehingga masih tergolong rendah (Zuraya, 2017). Rendahnya kredit yang diambil oleh UKM membuat pemerintah mengeluarkan kebijakan berupa penurunan suku bunga melalui program Kredit Usaha Rakyat sebesar 7\% dari 9\% mulai dari tanggal 1 Januari 2018 (Kompas.com, 2018).

Tingkat suku bunga merupakan balas jasa yang diberikan oleh bank kepada nasabah yang membeli atau menjual produknya. Bunga yang dimaksud disini adalah bunga pinjaman yang berarti harga yang harus dibayar oleh nasabah peminjam kepada bank seperti bunga kredit dan harga ini bagi bank merupakan harga jual (Kasmir, 2012:40). Beragamnya tingkat suku bunga yang ditawarkan membuat UKM bisa 
Jurnal Akuntansi \& Perpajakan, Volume 2, No. 1, Juli 2020

memilih untuk mengambil kredit perbankan atau tidak.

Kualitas pelayanan yang diberikan oleh pihak perbankan juga memengaruhi UKM dalam mengambil kredit perbankan. Kualitas pelayanan menurut Wykof dalam Tjiptono (2007:59) adalah tingkat keunggulan yang diharapkan dan pengendalian atas tingkat keunggulan tersebut untuk memenuhi keinginan pelanggan. Pendekatan teori pengambilan keputusan dapat dikaitkan dengan kualitas pelayanan yakni pemberian kualitas pelayanan yang baik oleh perbankan akan memberikan UKM pertimbangan dalam mengambil kredit.

Menurut Undang-Undang Nomor 10 Tahun 1998, jaminan adalah tambahan diserahkan nasabah debitur kepada bank dalam rangka mendapatkan fasilitas kredit atau pembiayaan berdasarkan prinsip Syariah. Adanya jaminan atau tidak yang disyaratkan oleh perbankan dapat dikaitkan dengan teori pengambilan keputusan dimana dengan ada atau tidaknya jaminan bisa menjadi acuan UKM dalam pengambilan keputusan.

Pada kurun waktu 2016, posisi kredit pada bank umum dan BPR di Kabupaten Cilacap mengalami kenaikan yang signifikan bila dibandingkan dengan kabupaten kota yang ada di Provinsi Jawa Tengah yakni sebesar Rp13,396 triliun dari tahun sebelumnya 2015 yang hanya Rp6,850 triliun (Badan Pusat Statistik, 2017). Dikutip dari data.jatengprov.go.id (2017)
Kabupaten Cilacap dan Banyumas adalah kabupaten dengan tingkat outstanding KUR tertinggi se-BARLINGMASCAKEB yakni sebesar lebih dari Rp200 miliar.

\section{KAJIAN LITERATUR}

Teori Pengambilan Keputusan

Menurut George R. Terry yang dikutip dalam Hasan (2002:10) teori pengambilan keputusan adalah pemilihan alternatif perilaku (kelakuan) tertentu dari dua atau lebih alternatif yang ada.

Kredit

Supramono (2009:152) menjelaskan pengertian kredit yang merujuk dalam Pasal 1 angka 11 UU Perbankan sebagai berikut: Kredit adalah penyediaan uang atau tagihan yang dapat dipersamakan dengan itu, berdasarkan persetujuan atau kesepakatan pinjam meminjam antara bank dengan pihak lain yang mewajibkan pihak peminjam untuk melunasi utangnya setelah jangka waktu tertentu dengan pemberian bunga.

Bank

Menurut Undang-Undang Nomor 10 Tahun 1998, bank adalah badan usaha yang menghimpun dana dari masyarakat dalam bentuk simpanan dan menyalurkan ke masyarakat dalam bentuk kredit dan atau bentuk-bentuk lainnya dalam rangka meningkatkan taraf hidup rakyat banyak.

Usaha Kecil Menengah 
Jurnal Akuntansi \& Perpajakan, Volume 2, No. 1, Juli 2020

Menurut Undang-Undang No 20 Tahun 2008 UKM memiliki pengertian dan kriteria sebagai berikut:

Usaha Kecil sebagaimana dimaksud dalam Undang-Undang ini yaitu memiliki hasil penjualan tahunan lebih dari Rp300.000.000,00 (tiga ratus juta rupiah) sampai dengan paling banyak Rp2.500.000.000,00 (dua milyar lima ratus juta rupiah).

Usaha Menengah sebagaimana diatur dalam Undang-Undang ini yaitu memiliki hasil penjualan tahunan lebih dari Rp2.500.000.000,00 (dua milyar lima ratus juta rupiah) sampai dengan paling banyak Rp50.000.000.000,00 (lima puluh milyar rupiah).

\section{Literasi Keuangan}

Menurut Xu dan Zia (2012) Literasi keuangan merupakan kesadaran dan pengetahuan tentang produk-produk keuangan, lembaga keuangan, dan konsep mengenai keterampilan dalam mengelola keuangan.

Tingkat Suku Bunga

Bunga bank menurut Kasmir (2012:40) dapat diartikan sebagai balas jasa yang diberikan oleh bank kepada para nasabah yang membeli atau menjual produknya.

Kualitas Pelayanan

Kualitas Pelayanan menurut Wykof dalam Tjiptono (2007:59) adalah tingkat keunggulan yang diharapkan dan pengendalian atas tingkat keunggulan tersebut untuk memenuhi keinginan pelanggan.
Jaminan

Jaminan menurut Usman (2008:66) merupakan kemampuan debitur untuk memenuhi atau melunasi perhutangannya kepada kreditur dilakukan dengan cara menahan benda tertentu yang bernilai ekonomis sebagai tanggapan atas pinjaman atau hutang yang diterima debitur terhadap krediturnya.

Pengaruh Literasi Keuangan terhadap Pengambilan Kredit Perbankan oleh UKM

literasi keuangan merupakan variabel yang terkait dengan teori pengambilan keputusan dimana literasi keuangan merupakan suatu pengetahuan mengenai pengelolaan keuangan yang baik, dapat menumbuhkan suatu keyakinan bagi pelaku UKM bahwa dengan mengetahui bagaimana mengelola keuangan yang baik, akan membuat keputusan yang baik dalam hal ini keputusan UKM dalam mengambil kredit perbankan. Penelitian yang dilakukan oleh Oktavianti et al. (2017) menyatakan literasi keuangan memiliki pengaruh signifikan positif terhadap akses kredit formal. Hal ini didukung oleh penelitian yang dilakukan oleh Tsalitsa dan Rachmansyah (2016) yang menyatakan literasi keuangan berpengaruh positif terhadap pengambilan kredit begitu pula sebaliknya. Berdasarkan uraian tersebut, maka hipotesis pertama dalam penelitian ini dapat dirumuskan sebagai berikut: 
Jurnal Akuntansi \& Perpajakan, Volume 2, No. 1, Juli 2020

H_1: Literasi keuangan berpengaruh positif terhadap pengambilan kredit perbankan oleh UKM.

Pengaruh Tingkat Suku Bunga terhadap Pengambilan Kredit Perbankan oleh UKM

Semakin tinggi suku bunga yang ditawarkan oleh perbankan akan membuat UKM mempertimbangkan untuk mengambil kredit di lembaga keuangan non bank sebaliknya dengan semakin rendahnya suku bunga yang ditawarkan akan dijadikan pertimbangan oleh UKM dalam mengambil kredit perbankan. Bukti impiris adanya pengaruh tingkat suku bunga terhadap pengambilan kredit perbankan oleh UKM ditemukan oleh Kaunang (2013) yang mengungkapkan bahwa tingkat suku bunga berpengaruh negatif terhadap permintaan kredit UMKM . Hal tersebut juga didukung penelitian yang dilakukan oleh Kuslin (2018) menyatakan bahwa suku bunga berpengaruh secara negatif terhadap permintaan kredit konsumsi. Mengacu pada hasil-hasil penelitian tersebut, maka hipotesis kedua dapat dirumuskan sebagai berikut:

$\mathrm{H} 2$ : Tingkat suku bunga berpengaruh negatif terhadap pengambilan kredit perbankan oleh UKM.

Pengaruh Kualitas Pelayanan terhadap Pengambilan Kredit Perbankan oleh UKM

Kualitas pelayanan yang diberikan oleh lembaga keuangan dalam hal ini perbankan akan menjadi pertimbangan oleh UKM dalam mengambil kredit perbankan. Kualitas pelayanan yang baik akan menjadi pertimbangan UKM untuk mengambil kredit. Secara empiris, hasil penelitian Chrisanti dan Saryadi (2017) yang menyatakan bahwa kualitas pelayanan berpengaruh positif dan signifikan terhadap keputusan nasabah mengambil kredit. Hal tersebut didukung oleh penelitian yang dilakukan Bramantyo (2017) yang menjelaskan bahwa kualitas pelayanan berpengaruh postif dan signifikan terhadap keputusan kredit UKM. Berdasarkan hasil-hasil penelitian sebelumnya, maka hipotesis ketiga dalam penelitian ini dapat dirumuskan sebagai berikut:

H3: Kualitas Pelayanan berpengaruh positif terhadap pengambilan kredit perbankan oleh UKM.

Pengaruh Jaminan terhadap Pengambilan Kredit Perbankan oleh UKM

Jaminan dapat berkaitan dengan teori pengambilan keputusan dimana dengan adanya jaminan atau tidak yang disyaratkan oleh perbankan akan dapat memberikan pengaruh terhadap UKM dalam mengambil kredit. Fungsi jaminan kredit adalah untuk melindungi bank dari kerugian. Dengan adanya jaminan kredit yang diberikan oleh UKM maka akan lebih meyakinkan bank dalam memberikan kredit. Penelitian yang dilakukan oleh Marta dan Satria (2015) menyatakan bahwa jaminan berpengaruh signifikan dan positif terhadap keputusan pengambilan kredit. Penelitian lain yang 
Jurnal Akuntansi \& Perpajakan, Volume 2, No. 1, Juli 2020

dilakukan oleh Efriyenty (2017) yang menyatakan jaminan berpengaruh positif terhadap keputusan UKM mengambil kredit. Berdasarkan uraian tersebut, maka hipotesis keempat dalam penelitian ini dapat dirumuskan sebagai berikut:

H4: Jaminan berpengaruh positif terhadap pengambilan kredit perbankan oleh UKM.

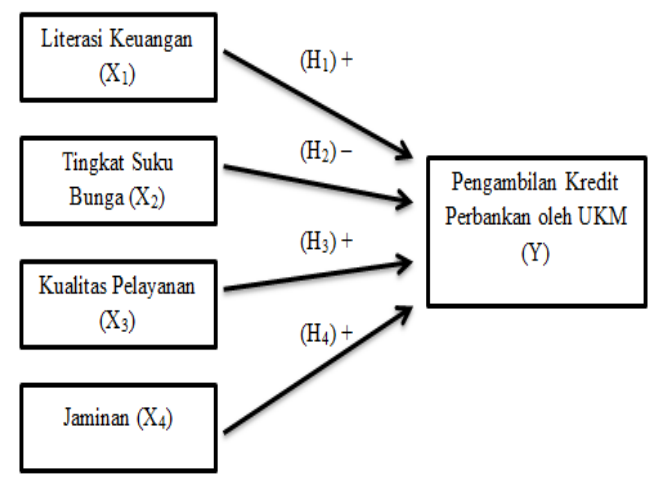

\section{METODE}

Populasi dan Teknik Pengambilan Sampel Jenis penelitian ini termasuk dalam penelitian kuantitatif dengan objek penelitian ini adalah UKM yang terdaftar pada Dinas Perdagangan, Koperasi dan UKM Kabupaten Cilacap. Data yang digunakan dalam penelitian ini adalah data primer dengan sumber data jawaban responden terhadap kuesioner yang sudah didistribusikan. Populasi dalam penelitian ini adalah UKM yang terdaftar pada Dinas Perdagangan, Koperasi dan UKM Kabupaten Cilacap yang berjumlah 1.870 unit. Teknik pengambilan sampel menggunakan purposive sampling dengan cluster terhadap pusat pengambilan sampel dan dibagi berdasarkan proporsi unit usaha, sehingga didapatkan 100 sampel.

Operasional Variabel

Literasi Keuangan (X1) menggunakan indikator pelaku UKM mengetahui literasi keuangan dan pelaku UKM mengetahui cara mengendalikan dana agar terus berjalan.

Tingkat Suku Bunga (X2) menggunakan indikator dengan penilaian pemberian tanggapan oleh UKM mengenai tingkat suku bunga pada perbankan.

Kualitas Pelayanan (X3) menggunakan indikator Tangible atau wujud penampilan dan Responsiveness atau daya tanggap.

Jaminan (X4) menggunakan indikator kemudahan menyediakan jaminan dan kredit dengan jaminan.

Pengambilan Kredit Perbankan oleh UKM (Y) menggunakan indikator mudah mendapatkan modal kerja dan dampak pada usaha.

Teknik Analisis Data

Analisis data yang digunakan yaitu Uji kualitas data (Uji validitas, Uji reliabilitas), Uji Asumsi Klasik (Uji Normalitas, Uji Multikolinearitas, Uji Heterokedastisitas), Analisis Regresi Linear Berganda, Uji Ketepatan Model (Goodness of Fit), Analisis Koefisien Determinasi $\left(\mathrm{R}^{2}\right)$ dan Pengujian hipotesis (Uji t).

\section{HASIL DAN KESIMPULAN}

Gambaran Umum Responden 
Jurnal Akuntansi \& Perpajakan, Volume 2, No. 1, Juli 2020

Penelitian ini mengambil lokasi di Kabupaten Cilacap. Populasi UKM yang berada di Kabupaten Cilacap berjumlah 1.870 dengan jumlah sampel sebanyak 100 responden. Sampel terbagi dalam 3 jenis usaha yakni manufaktur yang berjumlah 31 unit, dagang berjumlah 67 unit dan jasa sebanyak 2 unit.

\section{Validitas dan Reliabilitas}

Berdasarkan hasil uji validitas yang dilakukan terhadap jawaban responden diketahui nilai r_hitung > nilai r_tabel sebesar 0,374 pada tingkat kepercayaan 95\%. Dengan demikian, setiap item pernyataan pada semua variabel dapat dinyatakan valid dan dapat digunakan sebagai alat pengumpulan data. Hasil pengujian juga telah dilakukan untuk melihat tingkat reliabilitas dari instrument pada penelitian ini. Diapatkan nilai cronbach alpha untuk semua variabel diatas 0,60 dan instrument penelitian dikatakan reliabel.

\section{Hasil Asumsi Klasik}

Uji Normalitas, didapati nilai asymp. sig. (2-tailed) dari uji Kolmogorov-Smirnov Z untuk standardized residual variable adalah 0,113 lebih besar dari nilai $\square(0,05)$, sehingga dapat disimpulkan bahwa data yang digunakan berdistribusi normal.

Uji Multikolinearitas, didapati nilai VIF untuk variabel $\mathrm{X} 1=1,34, \mathrm{X} 2=1,17, \mathrm{X} 3=1,27, \mathrm{X} 4=1,13$, dengan demikian maka tidak terjadi gejala multikolinearitas karena nilai VIF $\leq 10$ dan nilai tolerance $\geq 0,10$.
Uji Heterokedatisitas, didapatkan nilai signifikansi untuk variabel $\mathrm{X} 1=0,32, \quad \mathrm{X} 2=0,19, \quad \mathrm{X} 3=0,20$, $\mathrm{X} 4=0,19$, dengan demikian maka model penelitian ini bebas gejala heterokedastisitas, karena nilai signifikansi di atas 0,05.

Hasil Analisis Regresi Linier Berganda

\begin{tabular}{llll}
\hline Variabel Bebas & $\begin{array}{l}\text { Koefisien } \\
\text { Regresi }\end{array}$ & Nilai thatug & Sig. \\
\hline Literasi keuang an $\left(\mathrm{X}_{1}\right)$ & 0,137 & 2,677 & 0,009 \\
Tingkat suku bunga $\left(\mathrm{X}_{2}\right)$ & $-0,028$ & $-0,677$ & 0,500 \\
Kualitas pelayanan $\left(\mathrm{X}_{3}\right)$ & 0,681 & 9,904 & 0,000 \\
Jaminan $\left(\mathrm{X}_{4}\right)$ & 0,194 & 3,814 & 0,000 \\
\hline Konstanta & $=0,125$ & & \\
Adj $R$ Square & $=0,673$ & & \\
$\mathrm{~F}_{\text {situs }}$ & $=51,952$ & & \\
$\mathrm{~F}_{\text {tat }}$ & $=2,45$ & & \\
$\mathrm{~S}$ ig. $\mathrm{F}$ & $=0,000$ & & \\
\hline
\end{tabular}

Koefisien regresi variabel literasi keuangan $\left(\mathrm{X}_{1}\right)$ adalah sebesar 0,137 , tingkat suku bunga $\left(\mathrm{X}_{2}\right)$ adalah sebesar -0,028, kualitas pelayanan $\left(\mathrm{X}_{3}\right)$ adalah sebesar 0,681 , dan jaminan $\left(\mathrm{X}_{4}\right)$ adalah sebesar 0,194, yang berarti jika keempat variabel meningkat, maka pengambilan kredit perbankan oleh UKM (Y) juga akan meningkat.

\section{Pengujian Hipotesis}

Nilai $\beta$ yang diperoleh dari analisis regresi berganda untuk variabel $\mathrm{X}_{1}$ menunjukkan angka 0,137 yang berarti variabel literasi keuangan memiliki pengaruh positif terhadap pengambilan kredit perbankan oleh UKM. Sedangkan nilai thitung variabel literasi keuangan 2,677 lebih besar dari nilai ttabel 1,661 dan signifikansi 0,009<0,05. Hasil uji statistik tersebut membuktikan bahwa secara parsial variabel literasi keuangan mempunyai pengaruh yang positif dan signifikan terhadap pengambilan kredit perbankan oleh UKM. Dengan demikian, hipotesis pertama yang menyatakan bahwa literasi keuangan berpengaruh 
Jurnal Akuntansi \& Perpajakan, Volume 2, No. 1, Juli 2020

positif terhadap pengambilan kredit perbankan oleh UKM diterima.

Nilai $\beta$ yang diperoleh dari analisis regresi berganda untuk variabel $\mathrm{X}_{2}$ menunjukkan angka 0,028 yang berarti variabel tingkat suku bunga memiliki pengaruh negatif terhadap pengambilan kredit perbankan oleh UKM. Sedangkan nilai thitung variabel tingkat suku bunga sebesar -0,677 lebih besar dari nilai ttabel -1,661 dan signifikansi $0,500>0,05$. Hasil uji tersebut menunjukkan bahwa secara parsial tingkat suku bunga berpengaruh negatif namun tidak signifikan terhadap pengambilan kredit perbankan oleh UKM. Dengan demikian, hipotesis kedua yang menyatakan bahwa tingkat suku bunga berpengaruh negatif terhadap pengambilan kredit perbankan oleh UKM ditolak.

Nilai $\beta$ yang diperoleh dari analisis regresi berganda untuk variabel $\mathrm{X}_{3}$ menunjukkan angka 0,681 yang berarti variabel kualitas pelayanan memiliki pengaruh positif terhadap pengambilan kredit perbankan oleh UKM. Sedangkan nilai thitung variabel kualitas pelayanan 9,904 lebih besar dari nilai ttabel 1,661 dan signifikansi 0,000 $<0,05$. Hasil uji statistik tersebut membuktikan bahwa secara parsial variabel kualitas pelayanan mempunyai pengaruh yang positif dan signifikan terhadap pengambilan kredit perbankan oleh UKM. Dengan demikian, hipotesis ketiga yang menyatakan bahwa kualitas pelayanan berpengaruh positif terhadap pengambilan kredit perbankan oleh UKM diterima.
Nilai $\beta$ yang diperoleh dari analisis regresi berganda untuk variabel $\mathrm{X}_{4}$ menunjukkan angka 0,194 yang berarti variabel jaminan memiliki pengaruh positif terhadap pengambilan kredit perbankan oleh UKM. nilai thitung variabel jaminan 3,814 lebih besar dari nilai ttabel 1,661 dan signifikansi $0,000<0,05$. Hasil uji tersebut membuktikan bahwa secara parsial variabel jaminan mempunyai pengaruh yang positif dan signifikan terhadap pengambilan kredit perbankan oleh UKM. Dengan demikian, hipotesis keempat yang menyatakan bahwa jaminan berpengaruh positif terhadap pengambilan kredit perbankan oleh

\section{UKM diterima.}

\section{Pembahasan}

\section{Pengaruh Literasi Keuangan terhadap}

\section{Pengambilan Kredit Perbankan oleh UKM}

Hasil pengujian $\mathrm{H}_{1}$ membuktikan bahwa literasi keuangan mempunyai pengaruh yang positif dan signifikan terhadap pengambilan kredit perbankan oleh UKM yang terdaftar pada Dinas Perdagangan, Koperasi dan UKM Kabupaten Cilacap. Hal itu berarti semakin tinggi tingkat literasi keuangan pelaku UKM, maka akan meningkatkan pengambilan kredit perbankan yang dilakukan oleh UKM.

\section{Pengaruh Tingkat Suku Bunga terhadap}

\section{Pengambilan Kredit Perbankan oleh UKM}

Hasil pengujian $\mathrm{H}_{2}$ membuktikan bahwa tingkat suku bunga tidak berpengaruh terhadap pengambilan kredit perbankan oleh UKM yang terdaftar pada Dinas Perdagangan, Koperasi dan 
Jurnal Akuntansi \& Perpajakan, Volume 2, No. 1, Juli 2020

UKM Kabupaten Cilacap. Hasil pengujian $\mathrm{H}_{2}$ mengindikasikan bahwa tingkat suku bunga kredit yang rendah tidak selalu diikuti dengan tingginya tingkat pengambilan kredit perbankan oleh UKM.

\section{Pengaruh Kualitas Pelayanan terhadap}

\section{Pengambilan Kredit Perbankan oleh UKM}

Hasil pengujian $\mathrm{H}_{3}$ membuktikan bahwa kualitas pelayanan mempunyai pengaruh yang positif dan signifikan terhadap pengambilan kredit perbankan oleh UKM yang terdaftar pada Dinas Perdagangan, Koperasi dan UKM Kabupaten Cilacap. Hal tersebut membuktikan bahwa semakin baik kualitas pelayanan yang diberikan oleh perbankan akan meningkatkan tingkat pengambilan kredit perbankan oleh pelaku UKM.

\section{Pengaruh Jaminan terhadap Pengambilan} Kredit Perbankan oleh UKM

Hasil pengujian $\mathrm{H}_{4}$ membuktikan bahwa jaminan mempunyai pengaruh yang positif dan signifikan terhadap pengambilan kredit perbankan oleh UKM yang terdaftar pada Dinas Perdagangan, Koperasi dan UKM Kabupaten Cilacap. Adanya syarat jaminan yang disyaratkan oleh pihak perbankan tidak membuat pengambilan kredit di perbankan menurun.

\section{KESIMPULAN}

\section{Kesimpulan}

Literasi keuangan berpengaruh positif terhadap pengambilan kredit perbankan oleh UKM.

Tingkat suku bunga tidak berpengaruh terhadap pengambilan kredit perbankan oleh UKM.
Kualitas pelayanan berpengaruh positif terhadap pengambilan kredit perbankan oleh UKM.

Jaminan berpengaruh positif terhadap pengambilan kredit perbankan oleh UKM.

\section{Implikasi}

\section{Secara Teoritis}

Secara teoritis penelitian ini diharapkan dapat memperkuat penelitian sebelumnya yang berkaitan dengan pengambilan kredit perbankan yang dilakukan oleh UKM. Selain itu penelitian ini juga dapat menjadi referensi metode penelitian dan analisis data untuk penelitian selanjutnya.

\section{Secara Praktis}

Rata-rata pelaku UKM di Kabupaten Cilacap sudah cukup mengetahui literasi keuangan. Diharapkan para pelaku UKM di Kabupaten Cilacap terus dapat meningkatkan literasi keuangannya, supaya dapat melakukan pengambilan kredit dengan tepat agar meningkatkan usaha para pelaku UKM.

Bagi kreditur diharapkan untuk meningkatkan kualitas pelayanannya karena rata-rata pelaku UKM sudah cukup setuju terhadap baiknya kualitas pelayanan perbankan. kemudahan syarat jaminan juga perlu diperhatikan kreditur karena para pelaku UKM cukup setuju dengan adanya syarat jaminan agar pengambilan kredit perbankan yang dilakukan UKM dapat terus meningkat.

Bagi pemerintah, tingkat suku bunga yang ada tidak terlalu diperhatikan oleh UKM. Penelitian 
Jurnal Akuntansi \& Perpajakan, Volume 2, No. 1, Juli 2020

ini diharapkan dapat dijadikan bahan pertimbangan dalam menentukan kebijakan yang berkaitan dengan sektor UKM dan perbankan.

\section{REFERENSI}

Badan Pusat Statistik. 2017. Posisi Kredit Rupiah dan Valuta Asing Bank Umum dan BPR Menurut Kabupaten/Kota di Jawa Tengah (Juta Rupiah) Berdasarkan Lokasi Proyek 2009 2016. Diakses 26 Juli 2018 dari jateng.bps.go.id..

Bramantyo, A. dan Sagoro, E. M. 2017. Pengaruh Kualitas Layanan, Prosedur Kredit, dan Promosi Terhadap Keputusan Kredit UKM. Jurnal Profita. 5. 1-15.

Chrisanti, Y. M. dan Saryadi. 2017. Pengaruh Tingkat Suku Bunga, Kualitas Pelayanan Dan Pendapatan Usaha Terhadap Keputusan Pengambilan Kredit (Studi Kasus Pada Nasabah BNI KCU UNDIP Semarang). E Journal UNDIP. 8-9.

Dinas Perdagangan, Koperasi dan UKM Kabupaten Cilacap. 2018. Data UMKM Kabupaten Cilacap.

Efriyenty, D. 2017. Analisis Faktor-Faktor Yang Mempengaruhi Pengambilan Kredit Oleh Pelaku Usaha Kecil Menengah Pada Debitur Bank Perkreditan Rakyat Kota Batam. Jurnal AKRAB JUARA. 2. 46-54.

Hasan, M. I. 2002. Pokok-Pokok Materi Teori Pengambilan Keputusan. Jakarta: Ghalia Indonesia.

Kasmir. 2012. Manajemen Perbankan (edisi revisi). Jakarta: PT Raja Grafindo Persada.

Kaunang, G. 2013. Tingkat Suku Bunga Pinjaman Dan Kredit Macet Pengaruhnya Terhadap Permintaan Kredit UKM di Indonesia. Jurnal EMBA. 1. 920-930.

Kompas.com. 2018. Sah, Suku Bunga KUR Jadi 7 Persen Mulai Tahun Ini. Diakses 14 Februari 2019 dari kompas.com.
Kuslin. 2018. Analisis Pengaruh Suku Bunga, Nilai Tukar dan Inflasi Terhadap Permintaan Kredit Konsumsi Di Sulawesi Selatan Tahun 20072016. Fakultas Ekonomi dan Bisnis Islam. Universitas Negeri Alaudin. Makasar.

Marta, J dan Satria, D. 2015. Dampak Jaminan terhadap Peluang Memperoleh Kredit bagi UKM di Sumatera Barat. Jurnal Ekonomi dan Pembangunan Indonesia. 16. 1-14.

Oktavianti, V., Hakim, M.S., dan Kunaifi, A. 2017. Pengaruh Literasi Keuangan dan Persyaratan Kredit terhadap Akses Kredit Formal pada UKM di Surabaya. Jurnal Sains dan Seni ITS. 6. 12-16.

Provinsi Jawa Tengah. 2017. Penyaluran Kur Per Wilayah Tahun 2017. Diakses 1 Oktober 2018 dari

http://data.jatengprov.go.id/dataset/penyalurankur-per-wilayah-tahun-2017.

Republik Indonesia. 1998. Undang-Undang Republik Indonesia Nomor 10 Tahun 1998 tentang Perubahan atas Undang-Undang Nomor 7 Tahun 1992 tentang Perbankan. Lembaran Negara Republik Indonesia Tahun 1998 Nomor 182. Sekretaris Negara Republik Indonesia. Jakarta.

2008. Undang-Undang Republik Indonesia Nomor 20 Tahun 2008 tentang Usaha Mikro, Kecil, Dan Menengah. Lembaran Negara Republik Indonesia Tahun 2008 Nomor 93. Sekretaris Negara Republik Indonesia. Jakarta.

Supramono, G. 2009. Perbankan dan Masalah Kredit, Suatu Tinjauan Di Bidang Yuridis. Jakarta: Rineka Cipta.

Tjiptono, F. 2007. Strategi Pemasaran (edisi kedua). Yogyakarta: Penerbit Andi.

Tsalitsa, A dan Rachmansyah, Y. 2016. Analisis Pengaruh Literasi Keuangan Dan Faktor Demografi Terhadap Pengambilan Kredit Pada PT. Columbia Cabang Kudus. Media Ekonomi Dan Manajemen. 1-13.

Usman, R. 2008. Hukum Jaminan Keperdataan. Jakarta: Sinar Grafika 
Jurnal Akuntansi \& Perpajakan, Volume 2, No. 1, Juli 2020

Xu, L dan Zia, B. 2012. Financial Literacy Around The World-An Overview Of The Evidence With Practical Suggestions For The Way Forward. The World Bank: Finance And Private Sector Development.

Zuraya, N. 2016. Indonesia Urutan Ketiga Dunia yang Tidak Melek Keuangan. Diakses pada 14 Februari 2019 dari republika.co.id.

. 2017. BI: Penyaluran Kredit UKM Indonesia Masih Rendah. Diakses pada 14 Februari 2019 dari republika.co.id. 